\title{
Resilience of organisations and territories: the role of pivot firms
}

\author{
Jean-Pierre Gilly \\ (Lereps, Université de Toulouse 1) \\ Med Kechidi \\ (Lereps, Université de Toulouse 2) \\ Damien Talbot \\ GREThA (UMR CNRS 5113) \\ Université de Bordeaux
}

In European Management Journal, 2014, vol. 32, n4, pp. 596-602

\section{Introduction}

This article aims to provide an answer to the following question: in an unstable economic context marked by rapid and profound technological changes, repeated financial crises and increasingly strict environmental constraints how can organisations and territories contribute to the maintenance of a high level of innovation while at the same time adapting to this turbulent environment? Answering this question pre-supposes the development of an analytical framework which will allow an understanding of both the adaptive ability of companies to innovate and the capacity of territories to favour this capacity. The concepts of organisational resilience and territorial resilience seek to take account of these phenomena.

The theoretical framework which we are trying to build, based on existing studies (Hassink, 2005; Swanstrom, 2008; MacKinnon et al., 2009; Pike et al., 2010), should allow us to understand how organisations, markets, technologies and territories evolve together in an open and unstable economic climate. Resilience is a notion seeking to capture the differential ability of places to react and respond to uncertain, volatile and rapid change (shocks including financial crises, climate change, extreme weather events) (Pike et al., 2010). For Boschma, Van Oort and Balland (2011), economic territorial resilience is the "capacity to resist unfavourable events by absorbing negative effects and maintaining its path" (p.4). But they add that resilience also has a more progressive character because it includes the "capacity to evolve more radically, by building a 'new' path upon existing resources" (p.4). The common thread of all these definitions is to see the phenomenon of resilience as a response to an external shock. But few studies explore the case where the changes are profound but progressive, of a more incremental than radical nature: this is the first theoretical gap that this article attempts to fill. 
Certain authors have started to explore the determinants of resilience. Thus, Bristow (2010) explains that this resilience depends on a few key elements: the diversity of activities, power being dispersed between numerous actors, mutually interdependent companies (as within a supply chain) or economic activities being integrated in local social networks. For other authors, resilience depends on the existence, within a territory, of a large number of small, innovative companies forming part of networks (Grabher, 2009). The accent is also placed on the necessity of recombining knowledge in order to go beyond traditional technological fields and develop new ones, thus opening up pathways for development (Suire, Vincente, 2010).

On the basis of these studies, three categories of determinants may be observed:

- technological diversity, transversality and recombination have an influence on processes of Territorial Resilience. In particular, related variety would seem to be a determining factor (Boschma, Van Oort, Balland, 2011): it expresses the idea that the greater the number of traditional, but technologically related companies to be found in a territory, the greater the probability that the territory will see new industries developing. This is, for example, the case when comparing the traditional aeronautical industry with the new on-board systems industry which covers the aeronautical sector, but also space, automobiles and railways;

- the structural properties of the networks are also an essential factor in resilience. Thus, the capacity of a network to allow its structure to evolve while avoiding lockin phenomena is crucial. In the same way, in relationships involving exchange of knowhow a centre/periphery structure seems to favour resilience (Suire, Vicente, 2010);

- the third major category of determinants of territorial economic resilience is found in the role, the strategy and the position of companies, research centres and institutions. Competitiveness clusters, local authorities and pivot firms appear to be central to resilience. They activate the relationships necessary to the recombination of know-how by favouring links between a variety of participants by, for example, managing value chains (Kechidi, Talbot, 2010).

This study is part of the analysis of this third category of determinants of resilience: we have chosen to examine the actors and the links which they form between them within a territory in order to successfully develop territorial resilience. In other words, we wish to put as much emphasis on those who act as on the results of their interactions. The first level of this analysis is that of the company, i.e. the micro-economic level, whereas the second is from the meso-economic point of view of the interactions between the different actors in the territory under consideration. We focus our analysis on a particular type of actor, that we call pivot firms (Cagli et al., 2009; Gilly et al., 2011; Kechidi, 2013; Talbot, 
2013). These are firms which have the technical and organisational capacity to coordinate a network of actors. For a given territory they are the key actors. There again, few studies attempt to link the organisational and territorial dimensions of resilience: this is the second theoretical gap that this work attempts to fill.

In order to do this, we develop a conception of resilience based on two dimensions:

- an organisational dimension which refers to the capacity of an organisation to manage a disturbance to its environment and to develop a new pathway;

- a territorial dimension which refers to the collective capacity of the actors to contribute to and to facilitate the development of territorial responses to external disturbances.

We intend to show in this article that taking into account the two dimensions organisational and territorial - simultaneously in the analysis allows the construction of a new approach to resilience. More precisely, it is a question of understanding how certain key organisations, in this case the pivot firms, contribute to the process of territorial resilience and, ultimately, why some regions resist and adapt better than others to shocks stemming from their environment.

The development pathways of territories and the organisations (including firms) located within them are not necessarily synchronised. However it is not possible to have dynamic firms in a territory that is not dynamic, and vice-versa. We wish to underline the fact that there is inevitably a dialogue between the development pathways of a territory and those of the actors within that territory.

This paper is essentially conceptual - an attempt to shed light on the links between organisational and territorial resilience through a focus on the pivot firm - organised in three parts. In the first part, we explain the organisational dimension of resilience. In the second part we explain the territorial dimension. In the third part, we deal more particularly with one type of actor, the pivot firm, which illustrates this double dimension of resilience.

\section{Organisational Resilience}

For numerous authors (Meyer, 1982; Weik, 1993 and 1999; Hamel, Välikangas, 2003; Hollnagel, 2006; Boin and McConnell, 2007), organisational resilience is the ability of an organisation to overcome an internal ${ }^{1}$ or external shock and to return to a stable state. For

\footnotetext{
${ }^{1}$ For example, the accidents to Challenger and Columbia are considered to result from internal events related to the organisation of NASA, to its decision-making system, to its learning methods, etc. (Vaughan, 2005;
} 
Altinas and Royer (2009) resilience is explicitly the "capacity of an organisation to maintain or return to a dynamic stable state which allows it to continue its operations during and after a major incident or in the presence of a continuous stress" (p. 267). The factors leading to resilience are: the setting up of systems of centralisation of authority (Barnard, 1938; Hermann, 1963; Meyer et al., 1990), to the rationalisation of the management of financial and human resources (Huy, Mintzberg, 2003; Meyer et al., 1990), to the development of new marketing strategies, to innovation or to the diversification of the range of activities of the company (Meyer, 1982).

In these approaches, resilience is relative to the ability to resist and to manage a disturbance of the environment. They equate resilience to an organisational slack which cushions and absorbs external shocks (Meyer, 1982). Organisational resilience is seen mainly as the ability to resist an external shock and to overcome it. Only one component of organisational resilience is analysed, i.e. capacity for resistance. This is a view which does not adequately take into account the capacity of an organisation to anticipate and to create new development pathways. Now, "in a turbulent age, the only dependable advantage is a superior capacity for reinventing your business model before circumstances force you to" (Hamel, Välikangas, 2003, p. 2). We consider organisational resilience to be a double capacity of resistance and adaptation opening the way for new pathways. These pathways indicate the capacity of an organisation to find novel responses to new questions and not simply to reproduce previously-used organisational responses.

\subsection{Organisational resilience: a dual capacity of the organisation}

When analysing resilience, the notion of an "event" occupies a central place. This event is generally a shock, i.e. a discontinuity or a break with an existing situation in technological, organisational or market terms (Pauchant, 1988; Boin, 2005; Altinas, Royer, 2009). This is the case of a crisis or of any other major, unanticipated event. An external event may also take the form of a continuous process of change in the environment of an organisation. Such change is not then expressed by a shock but by a repeated pressure from environmental factors (market dynamics, behaviour of current or potential competitors, speed of innovation, etc.). The impacts of these two types of events are obviously not the same. In the first case, the organisation reacts to its environment. In the second, the events are anticipated and integrated.

Organisational resilience refers to a double capacity: that of resisting a shock or limiting its effects but also that of anticipating and thus adapting to this shock or to a rapid evolution in the economic context by creating new systems, particularly organisational ones. Such a

Farjoun and Starbuck, 2005). In the remainder of this paper, we will confine ourselves to disturbances from the external environment. 
capacity pre-supposes that the organisation has a certain number of skills, seen here as a set of resources mobilised in order to resolve a complex problem or a hitherto unknown production problem. Organisational resilience takes into account the existence within an organisation of two categories of skills: on the one hand, skills related to managing an external event (crisis management) and, on the other hand, skills relating to technical and organisational innovation in order to go beyond the crisis and to open a new pathway towards expansion.

Thus we adopt the point of view according to which "resilience refers to a capacity for continuous reconstruction. It requires innovation with respect to those organisational values, processes and behaviours that systematically favour perpetuation over innovation" (Hamel, Välikangas, 2003, p. 4). Thus an organisation is resilient when, faced with continuous or discontinuous environmental pressure, it has the capacity to absorb and/or anticipate these mutations by developing a new growth dynamic. At this point the question of the nature of these capacities must be posed.

\subsection{The foundation of organisational resilience: the skills of the organisation}

Numerous studies find the basis of these capacities in the quality of the skills available within organisations. These skills are made up of the knowledge and know-how of the individual members of the organisation but also by the knowledge and practices held in the organisation's memory. Cooke (2010) gives a good example of the resilience of organisations when he talks about Silicon Valley companies after the bursting of the Internet bubble in 2001 . These companies were able to develop new products because they had, inhouse, the necessary skills to produce new, even unexpected responses to external shocks. For Hill et al. (2008) individual skills are the basis of a form of organisational resilience. Thus, they show that after the recession in 2000, centres specialising in computer services produced better results than those in the manufacturing industry because of their highly qualified workforce.

These two examples, and there are many others, indicate clearly that in order to understand the resilience of a region, of the territory where companies are established, it is necessary to examine the companies themselves and the responses which they develop in the face of a turbulent environment. These organisational responses are based on the distinctive skills of the organisation, those which allow it to respond to shocks or recurring pressure from environmental factors which lead others to fail and disappear.

Weick (1990; 1993) and Weick and Roberts (1993) offer a cognitive approach to organisational resilience. For these authors, individual and collective learning are the origin of the development of a collective memory for the organisation. This memory is made up of the totality of the knowledge, know-how, procedures, standards, and operating methods of 
the activity and the organisational systems and the forms of interaction between its members. This memory can allow an organisation to find technical and organisational responses when confronted with an event which is potentially disturbing to its activity. Riolli and Savicki (2003) add that if the factors contributing to organisational resilience are strongly influenced by the nature of the learning acquired by the organisation (all of its knowledge and know-how) they are also strongly influenced by the nature of the methods of coordination that it puts into place. With the concept of "resourcefulness" MacKinnon and Derickson (2013) also stress the relational character of resilience, which refers to the ability of actors to establish interactions in order to develop learning ${ }^{2}$. Modes of coordination structure relationships between individuals as well as those between organisations. Their nature will have an impact on the contents and the form of these relationships. Two complementary modes of coordination may be observed in a company (Talbot, 2010). The first aims at the acquisition, the conservation and the transmission of knowledge, representations, knowhow, experiences, etc. The second seeks to give coherence to contradictory aspirations, to regulate latent conflicts, to prioritise problems, to impose arbitration, to establish compromises. In effect, within a company, resilience pre-supposes that the actions of groups with different statuses and interests (shareholders, directors, employees, trade unions) articulate one with another. Beyond the sharing of knowledge, the existence of a compromise between the different stakeholders in the organisation is necessary in order to generate organisational resilience.

Thus, finally, it is the nature of the knowledge acquired by an organisation, (i.e. its cognitive capital), and the specificity of its mode of governance (i.e. its nature and its quality), which form the basis of the resilience of an organisation.

Thus, when faced with an external event which manifests itself in a discontinuous or continuous way, an organisation will develop two types of response depending on the nature of its internal skills and of its modes of coordination. We formulate two proposals concerning the behaviour of the organisation:

- Proposal 1: the organisation possesses sufficient information and knowledge to deal satisfactorily with the uncertainty relating to its activity. This uncertainty is then "absorbed" by the compatibility of the response with the event which triggered it. The organisation does not need to innovate in order to respond to such disturbances. The uncertainty is stabilised by the set of existing organisational systems (information systems, monitoring systems, organisational procedures, etc. and modes of governance). In this case, the response measures the aptitude of an organisation to deal with disturbances to its environment without incurring new cognitive costs;

\footnotetext{
${ }^{2}$ We completely agree with the authors that one must be careful when importing a concept - such as resilience - first developed in the life sciences into social relations. For us, resilience is
} 
- Proposal 2: The organisational memory is insufficient to deal with these circumstances and the uncertainty is not "absorbed". The organisation does not hold all the information or knowledge necessary for the response: the organisation must develop a new, original response. Two situations are then possible. Either the

not the return to the state of equilibrium that existed before a perturbation (ecological viewpoint). A system is resilient when it moves to a qualitatively new state, when it moves into a new development pathway. However, it seems to us that the problem they address is the normative, political and ideological use of such concept by authorities and government actors. This is not, however, our approach.

organisation possesses the in-house skills which will allow it to develop new technical and organisational responses and to develop new directions of growth (overcoming the crisis). Or it does not have these means and its survival is called into question. The organisation may also seek, through external cooperation, for example located in the same territory, the skills which it lacks (see below). Whatever the situation, the nature of the response depends on the nature of the skills within the organisation.

In the end, organisational resilience is based on the nature and the quality of collective skills, skills which are the basis for two abilities:

- that of absorbing, anticipating and resisting an external event;

- that of generating new technical and organisational solutions when faced with hitherto unknown technical and organisational problems.

In the case where an organisation makes up for its lack of knowledge through cooperation, it must use relationship skills in order to join networks of actors which are non-spatial (global) and/or within territories (local networks). What becomes important in this situation, beyond complementary skills, is the existence of trust between the actors, common representations, shared and accepted rules, similar values (Colletis, 2010). This relates to a specific mode of governance which allows this opening towards new relationships. In the situation involving a network within a region, the company becomes part of a system of local interactions governed by rules between participants with complementary skills linked by the sharing of a common space, a common objective: for example a production-related project. It is within this context that we can consider that organisational resilience contributes to territorial resilience. 


\section{Territorial resilience}

According to Grabher (2009), in order to understand the phenomenon of territorial resilience, it is necessary to call on three principles: (1) the localised nature of innovation, (2) the life cycles of firms, industries and regions, (3) the role of institutions and socioeconomic culture. For Simmie and Martin (2010), territorial resilience is an "adaptive capacity" specific to a territory: "[...] it is the differential ability of a region's or a locality's firms to adapt to changes and shocks in competitive, market, technological, policy and related conditions [...]" (p. 29). From this point of view, we take territorial resilience to be the ability of a territory to regain a dynamic state and to find a new pathway after a major perturbation in its environment. This territorial resilience is the result of the collective ability of the actors from the territory to build a response in order to resist external events, be it a sudden crisis or a marked change in the productive and technological context. This ability includes that of being able to absorb the impact of this event. Thus, organisations' own capacities for resilience contribute largely to the outcome of the process of territorial resilience. This conception of territorial resilience is linked to a specific definition of the notion of territory.

\subsection{Territories: agglomeration territories, specification territories}

The notion of territory that we propose is meso-economic and may be understood in terms of proximity. One can speak of a territory when three types of proximity (organisational, institutional and geographical) operate together. Institutional proximity equates to the "rules of the game" accepted by the actors and which characterise territorial governance. These rules define the role of each participant and allow the convergence of representations, standards, values, etc. Organisational proximity is a potential for cooperation based on the complementarities of skills that is revealed by institutional proximity and depends on the problem to be resolved (Gilly, Torre, 2000). It opens the way for technical-productive relationships of actors within a value chain, an innovation process, etc.

Institutional and organisational proximities are potential factors whose existence conditions the reality of a relationship between actors. This is not the case with the third type of proximity (geographical proximity): a relationship can obviously exist between actors who are physically remote from one another i.e. without geographical proximity. Geographical proximity can destroy a relationship by proving to be a source of conflict (cf. conflicts of use). But it can also reinforce it and help it to last. In effect, geographical proximity facilitates face to face interactions and thus facilitates exchanges. In particular, face to face communication facilitates the diffusion and recombination of heterogeneous knowledge and reduces the opportunism of the participants (Boschma, 2005). And Kechidi and Talbot (2010) remind us 
that face to face communication allows new problems to be dealt with and resolved when none of the participants taken in isolation would have the capacity to do so.

These combined proximities thus constitute a potential which, if it is activated by the interplay of the participants, reveals the existence of a territory (Gilly, Torre, 2000). One can distinguish two extreme categories of territory:

- on the one hand, the agglomeration territory which refers to a spatial concentration of heterogeneous actors and activities. The agglomeration creates technological externalities that companies can seek to capture by gathering near the source of these externalities (Krugman, 1995). Holding non-complementary resources and being part of a system of weak territorial governance, these actors maintain classical market-based relationships and do not try to coordinate their activities with the objective, for example, of collectively producing a new technology;

- on the other hand, the specification territory spatially concentrates participants with complementary skills and activities, for example around a production-related problem. One can speak of a specification territory when the territorial productive organisation, thanks to the relationships between local participants, has the collective capacity to bring to light and to resolve a production-related problem (among other things to generate a new technology). This capacity allows the territory to open up to a multiplicity of technical-productive pathways.

In the center of a continuum describing the different forms of territories, certain authors distinguish the specialisation territory which concentrates participants belonging to the same industry and following very specialized development pathways in one type of industry. More precisely, for Colletis et al. (1999) specification may be observed in the capacity for change in the economic fabric when faced with a given productive problem. The concept of specification is used here to define the ability of the actors in a territory to identify new opportunities for development and to redeploy resources in relation to these opportunities. This supports some of the studies which explain the emergence and the operation of clusters (Suire, Vicente, 2009) or of those which deal with the territory as a provider of collective skills capable of resolving problems (Gilly, Torre, 2000). The specification territory is thus a territory made up of collective skills and relational combinations between actors forming its capacity for resilience

\subsection{Territorial resilience: the collective skills of a specification territory}

Whereas organisational resilience operates within a single organisation, territorial resilience refers to specific capacities shared by geographically closely-related actors. There are three 
of these capacities, which are equivalent to stages in the formation of a specification territory. We make three proposals concerning the nature of these capacities:

- Proposal 3: territorial resilience is based on the collective capacity of the actors to materialise a common production-related problem, to share a common aim. When an actor possesses the skills to resolve a difficulty alone, we are still dealing with a case of organisational resilience. If the actors, considered individually, do not have this capacity for resolving the problem and see, by cooperating at the territorial level, the means to resolve a problem that is beyond them individually then the resilience becomes territorial. This may be considered as a reciprocal acceptance of the need for a collective response to a problem understood as being common to all concerned;

- Proposial 4: because they have identified a common production-related problem, the actors within a territory are now able to reach compromises in order to harmonise their strategies within a local productive organisation. These compromises are based on the definition of a common timeframe, on the complementary skills and physical resources to be brought into play in order to resolve the problem, on the distribution of the results hoped for from the collaboration, on the concrete aspects of the forms of cooperation, etc. These compromises signify the establishment, by the actors, of a territorial system of governance which regulates collective action. The notion of territorial governance enlarges that of institutional proximity;

- Proposal 5: the actors are then able to create common learning processes and thus to innovate. The existence of this capacity for collective learning, by organising a flexible approach to the combination and re-combination of complementary skills, allows the opening up of the territory to a multiplicity of development pathways. Here the specification aspect of the territory is essential because it is above all the complementary character of the skills and the capacity of the actors to develop relationships that allow the territory to be redeployed, by avoiding lock-in phenomena which are encountered, for example, by territories engaged in specialisation pathways (Colletis, 2010). Faced with new technical-production problem, the actors work together permanently to find new responses (technical, organisational and relational) and new forms of territorial governance and thus become part of a process of territorial resilience. They thus build a memory (technical, organisational and relational) shared between them and nourished by the memories of the participants in the interaction.

It seems to us that it is the taking into account of these three capacities that can help to understand why, for example in the previously quoted case of Silicon Valley, firms were able to find new development prospects after the bursting of the Internet bubble, by investing in biotechnologies and cleantech as a source of new growth (Cooke, 2010). Work by Simmie and Martin (2010) supports this idea when they show that the resilience of the Cambridge region is due to the capacity demonstrated by the actors to recombine their blocks of 
knowledge and skills in alignment with the emerging technological paradigms. In the same way, in the region of Toulouse, France, the work of Gilly et al. (2011) shows that pivot firms such as Liebherr and Thales play a central role in the regional dynamic and in its capacity for resilience.

Finally, the specification territory really is a territory within which territorial resilience can be deployed: such a resilience is characterised by a triple capacity to materialise a common problem, to make compromises between the actors in the territory and to organise collective learning as an adaptive and creative response to an external change or shock in the competitive, market and technological conditions for the period under consideration.

\section{The key role of pivot firms: articulating organisational resilience and territorial resilience}

Within such a specification territory, the actors always occupy asymmetrical positions. Certain are dominant and constitute the key actors. Public or private, they play a determining role in the local technical-productive organisation but also in the development of the institutional references for the actors in the territory, foundations of territorial resilience. The key actor favours relationships between organisations (companies, research centres, universities, local authorities, etc.) particularly in terms of skills, in order to develop, collectively and permanently, the new technologies which are necessary for it. In this way it plays a determining role in the stabilisation of the rules of the game of the actors or in the emergence of a new form of territorial governance.

In our view, the key actor could just as well be an economic actor (company) as an institutional actor from the public (local authority) or private sector (association, trade union). We are now going to shed light on a new category of key actor, the pivot firm, which is tending to play a decisive and increasingly important role within certain specification territories.

\subsection{Pivot firms: an example of organisational resilience}

In numerous industrial or service activities, recent technological developments show a clear increase in the complexity of products and the incorporation of more and more complex and varied technologies (Catel, Monatéri, 2007). The multiplicity, the increasing complexity and the widening of the field of productive activities make it difficult for a single company to master all the functions related to technological innovation and development activities. 
Consequently a cognitive division of the work has progressively become established based on the skills of the participants in the productive project. "The production process is broken down into homogeneous blocks of know-how. As a first approximation, a block of know-how may be defined as a set of knowledge referring to the same body of scientific and technical principles, subject to a common dynamic of evolution and transformation" (Moati, Mouhoud, 1994, p. 54). If this is the case, one can characterise a technical object as a combination of differentiated blocks of knowledge. Consequently, at least two types of skill appear: those relating to the mastery of the

"scientific and technical principles" associated with each block of knowledge and those relating to the combination of these blocks to make the final product. These combinatory skills relate to the manner in which the components and subsets are integrated and linked together into a coherent whole (Henderson, Clark, 1990).

Numerous studies have thus shown that these mutations have been at the origin of new organisational architectures, whether one considers the intra-company or inter-company level (Baldwin, Clark, 2000; Langlois, 2002; Sturgeon, 2002). Others deal more specifically with the structuring of the network and the role played by certain actors in these new architectures. The terminology to describe this group of actors is multiplying. "Hub firms" (Jarillo, 1988), called "pivot firms" par Guilhon and Gianfaldoni (1990) or "brokers" by Miles and Snow (1992), and Dhanasai and Parkhe (2006) are in a position to control the network of subcontractors. Strategic network analyses have developed the idea that the core of a network or "pivot firm" plays an essential role in these new architectures (Fréry, 1998). These pivot firms are in a position to control the network (Jarillo, 1988). Guilhon and Gianfaldoni (1990) underline the fact that the network of companies is organised around a "pivot firm", referred to as a "broker" by Miles and Snow, (1992), as "focal firms" by Lorenzi and Baden-Fuller (1995), "flagship firms" by Rugman and D'Cruz (2000) or "network orchestrators" by Dhanasai and Parkhe (2006). This coordinating company must "manage a value chain" (Fulconis, Paché, 2005), exercise "local leadership" over part of the supply chain, particularly through project management (Fabbe-Costes, 2005). The focal-point company, by controlling the flow of information and by management of the various communication tools (Lorenzi, Baden-Fuller, 1995), organises the specialisation of the members of a network in the sense of an asymmetry of power and of roles (De Propis, 2001). For these authors, the focal-point firm becomes the designer of the network. Certain authors have described the skills possessed by pivot firms in order to play their role. Fréry (1998) stresses their ability to conceive the design of the value chain, to run it, to deal with conflicts and to evaluate the members of the chain, while other authors see their role as that of technical and organisational coordinator of the participants in a production-related project (Kechidi, 2008; Cagli, Kechidi, Levy, 2009; Gilly, Talbot, Zuliani, 2011).

The re-centring of a company on know-how which is essential to its job is a response to the increasing complexity of technologies at the same time as its ability to (re)combine the skills 
held by other actors. Specifically, we develop the point of view according to which the emergence of a particular organisational form, the pivot firm, constitutes such a response to current mutations in productive processes. Responsible for the design and/or production of a subset of the final product and the technical and organisational interfaces with the other actors making up the production chain, the pivot firm shows the ability to develop and manage interactions with the other participants in the productive project.

In order to put this ability into practice, the pivot firm possesses several essential skills.

First it possesses specific technical skills which can be brought into play for the design and production of a major element of the production process. Possessing a homogeneous block of knowledge, it can play the role, at its level, of architect for the elements which are entrusted to it. In order to do this, it possesses combinatory, technical, organisational and relational skills. These skills are brought into play at the moment when the technical modules, previously broken down into subunits, are reassembled and in terms of the coordination of the actors which take part in this reconstitution. They indicate the ability to mediate between the architect company at the top of the pyramid which designs and assembles the complex product and the other actors spread over different levels which supply components and subsystems. In order to carry out this role of mediation, the pivot firm develops modes of governance.

Pivot firms are generally firms from a particular industry which are very specialised. For example in the aeronautical field (Kechidi, 2013; Talbot, 2013), the construction of an aircraft is carried out under the responsibility of an architect-integrator of aeronautical systems (Airbus or Boeing), by a small number of pivot firms which are very specialised in a particular block of knowledge (Thales, Goodrich, Honeywell Liehberr, Rockwell, Vought, Alenia, etc.) and a whole network of small and medium-sized companies which are highly diversified and geographically close together. Other work of the same nature has been carried out previously in the automobile industry (Guilhon and Gianfaldoni, 1990).

Finally, the pivot firm, faced with increasing complexity and intensification of the fields of knowledge that it must be able to bring into play in order to maintain its place in the supply chain, faced with the necessity of taking charge of the design and development of bigger and bigger systems, is an example of organisational resilience. The pivot firm has been able to develop the know-how and the modes of governance necessary for its adaptation. When this process of adaptation is carried out in association with actors who are geographically close, it participates in the development of territorial resilience. In this sense, it articulates organisational and territorial resilience. 


\subsection{The pivot firm and the development of territorial resilience}

In its technical-productive dimension, the combinatory capacity of the pivot firm expresses itself by its cooperation with other companies (industrial and service), research bodies (public and private) and institutions. When these relationships develop in a localised geographical area, they can help to construct a specification territory. In this configuration, beyond its capacity to combine products and/or technologies and to coordinate the local actors which produce them, the pivot firm, in its most highlydeveloped form, represents an organisational structure which facilitates the circulation and above all production of knowledge, know-how and technologies at the territorial level.

In such a territory, the pivot firm is not the only actor to organise such cooperation. The presence of intermediary structures (often set up by local public institutions) facilitates the meeting of the pivot firm with local actors (research centres, networks of SMEs, etc.). These structures participate both in the codification and the development of the shared rules and common values which make up institutional proximity (and, beyond that, territorial governance) and in the development of organisational proximity. The pivot firm becomes a key actor in the territory inasmuch as it lies both at the heart of the dynamic of local technical-productive organisation (organisational proximity) and at the centre of the institutional references (institutional proximity) which orientate the behaviour of local actors. Thanks to its combinatory skills it generates territorial resilience in its organisational and institutional dimensions.

In fact, pivot firms show a capacity to take part in the structuring of a territory through dense networks of partner firms and research centres able to supply specific skills. Such a process, indicative of a specification territory, generates innovations which enrich both the technical and organisational skills of the pivot firms and the process of territorial resilience based on collective learning by the actors as well as on the development of compromises and common institutional references.

\section{Conclusion}

Finally we obtain two theoretical results in this essentially conceptual study. The first contribution consists of identifying two categories of external events triggering a process of resilience: certainly crises of a radical nature, but also profound productive and technological developments of a more incremental nature. On the basis of an approach considering resilience as a set of capacities (based themselves on skills specific to the actors), we have defined organisational resilience as: first, a reactive capacity of the company to resist an external event; second, a more active capacity to anticipate events and thus open new development pathways. This organisational resilience is based on the cognitive capital possessed by the firm and the specificity of its modes of governance (intra- and interorganisational). 
The second theoretical contribution of this paper is that we propose a definition of resilience which takes into account simultaneously the organisational and territorial dimensions. It is true that organisational resilience may seek to make up for a lack of knowledge by opening up towards new forms of cooperation, for example on the basis of a territory. In fact, the positive effects of geographical proximity (increased possibility of face-to-face meetings, reduction in opportunistic behaviour) will favour exchanges and the recombination of knowhow which are necessary to the development of cognitive capital.

It is this dynamic which is the basis of territorial resilience. Territorial resilience includes three collective capacities of the actors: first, materialise a common problem; second, make compromises in order to harmonise their strategies; third, organise a joint learning process in order to innovate.

The pivot firm is a key actor able to link these two types of resilience, internal and external to the organisation. In effect it stands apart thanks to its capacity to manage the interfaces between industrial organisation and territorial creation of technologies. The pivot firm proves to be capable of both:

- $\quad$ fitting into a process of innovation and creation of territorial resources issuing from the interplay of localised relationships established with strategic partners, innovative SMEs, research centres, etc.;

- linking this territorial process with a double process: on the one hand, a technological process which is internal to the company and, on the other hand, a co-specification process with strategic partners.

In the same way, the pivot firm appears as a company linking industrial dynamics and territorial dynamics and thus participating in the sectorial reorganisations currently taking place.

Finally, this conceptual paper has allowed us to formulate a set of theoretical proposals which call for in-depth empirical validation. Fieldwork is indispensable in order to test them. Beyond the aeronautical industry, already referred to in this study, the automobile industry, for example, is no doubt a field of investigation to be pursued in future work both because it is undergoing a major crisis and because it includes numerous locallybased pivot firms.

\section{Bibliography}

Altinas G. and Royer I, 2009. Renforcement de la résilience par un apprentissage postcrise : une étude longitudinale sur deux périodes de turbulences, M@n@gement vol 12 n4, 266293.

Baldwin and Clark, 2000. Design rules: The power of modularity. The MIT Press. 
Barnard, C. I. (1938). The Functions of the Executive. Cambridge, MA: Harvard University Press

Boin, A. (2005). From crisis to disaster: Toward an integrative perspective. In R. Perry \& E. L. Quarantelli (Eds.), What Is A Disaster? New Answers to Old Questions (pp. 153-173). Philadelphia: Xlibris Press.

Boin, A., \& McConnell, A. (2007). Preparing for critical infrastructure breakdowns: The limits of crisis management and the need for resilience. Journal of Contingencies \& Crisis Management, 15(1), 50-59.

Boschma R., 2005. Proximity and innovation. A critical assessment, Territorial Studies, vol.39, $\mathrm{n}^{\circ} 1,61-74$.

Boschma R., Van Oort F., Balland P.A., 2011. Related variety, knowledge transfer and economic territorial resilience: some research options, T-RES kick-off meeting, LEREPS, Toulouse, 24-25 March.

Bristow G. 2010. Resilient territories: re-'place'ing territorial competitiveness, Cambridge Journal of Territories, Economy and Society, vol. 3, n¹, 153-167.

Cagli A., Kechidi M., Levy R., 2009. Gestion stratégique de la supply chain et firme-pivot dans le secteur aéronautique, Revue Française de Gestion Industrielle, n², juin 2009,. 236251.

Catel F. , Monatéri J-C., 2007. Modularité et dynamique des relations durables entre entreprises : le cas des produits et systèmes complexes, Working paper LEFI, University Lyon Lumière

Colletis G., 2010. Co-évolution des territoires et de la technologie : une perspective institutionnaliste, Revue d'Economie Régionale et Urbaine, $\mathrm{n}^{\circ} 2,235-250$.

Colletis G., J.-P. Gilly et al. (1999). Construction territoriale et dynamiques économiques", Sciences de la Société, $n^{\circ} 48$, octobre, pp.25-47.

Cooke, P. 2010. Transversality and Transition: Branching to new regional path dependence, Prepared for the New Path Creation workshop at Trinity College, Oxford, September 5-7.

Dhanasai C., Parkhe A., 2006. Orchestrating Innovation Networks, The Academy of Management Review, vol. 31, n³, 659-669.

De Propis L., 2001. Systemic Flexibility, Production Fragmentation and cluster Governance, European Planning Studies, vol. 9, $n^{\circ} 6,765-782$. 
Cooke, P. 2010. 'Transversality and Transition: Branching to new regional path dependence'. Prepared for the New Path Creation workshop at Trinity College, Oxford, September 5-7, 2010.

Fabbe-Costes N., 2005. "La gestion dynamique des supply chains des entreprises virtuelles", Revue Française de Gestion, vol. 31, n 156, 151-166.

Fréry F., 1998. Les réseaux d'entreprises : une approche transactionnelle, in Repenser la stratégie. Fondements et perspectives, H. Laroche et J.P. Nioche (éds), Vuibert, Paris.

Gilly J.P., Torre A., (eds), 2000. Dynamiques de proximité, L'Harmattan, Paris.

Gilly J.P., Talbot D., Zuliani J.M., 2011. Pivot firms and the dynamics of territorial innovation: case studies of Thales and Liebherr in Toulouse, European Planning Studies, vol. $12, n^{\circ} 3$, 2004-2023.

Grabher G., 2009. Yet another turn? The evolutionary project in economic geography, Economic Geography, Economic Geography, vol. 85, issue 2, 119-127.

Guilhon B., Gianfaldoni P., 1990. Chaînes de compétences et réseaux, Revue d'Economie Industrielle, vol. 51, $\mathrm{n}^{\circ} 1,97-112$.

Hamel, G., \& Välikangas, L. (2003). The quest for resilience. Harvard Business Review, 81(9), pp. 52-63.

Hassink R., 2005. How to unlock territorial economies from path dependency. From learning territory to learning cluster, European Planning Studies, vol. 13, 521-535.

Henderson R., Clark K, 1990. Architectural innovation: the reconfiguration of existing product technologies and the failure of established firms, Administrative Science Quaterly, vol. 35, $n^{\circ} 1,9-30$.

Hermann, C. F. (1963). Some consequences of crisis which limit the viability of organizations. Administrative Science Quarterly, 8(1), 61-82

Hill, E., Wial, H., Wolman, H. (2008) Exploring regional economic resilience, Working Paper, Institute of Urban and Regional Development, $\mathrm{N}^{\circ} 04$

Hollnagel, E. (2006). Resilience: The challenge of the unstable. In E. Hollnagel, D. D. Woods \& N. Leveson (Eds.), Resilience Engineering: concepts and precepts pp. 917);Burlington, Ashgate. 
Huy, Q. N., \& Mintzberg, H. (2003). The Rhythm of Change.MIT Sloan Management Review, 44(4), pp. 79-84.

Farjoun, M., \& Starbuck, B. (2005). Lessons from the Columbia disaster. In W. H. Starbuck \& M. Farjoun (Eds.), Organization At The Limit: Lessons From The Columbia Disaste.

Fulconis F., Paché, G., 2005. Piloter des entreprises virtuelles : un rôle nouveau pour les prestataires de services logistiques, Revue française de gestion, vol. 3, n¹56, 167-186.

Jarillo J.C., 1988. On strategic networks, Strategic Management Journal, vol. 9, 31-41.

Kechidi M., 2008. Modularité, firme-pivot et innovations : un nouveau modèle d'organisation industrielle pour Airbus?, Revue Française de Gestion Industrielle, $n^{\circ} 2,21$ 40.

Kechidi M., Talbot D., 2010. Institutions and coordination: what is the contribution of a proximity-based analysis? The case of Airbus and its relations with the subcontracting network, International Journal of Technology Management, vol. 50, n³/4, 285-299.

Kechidi, M. (2013) 'From 'aircraft manufacturer' to 'architect-integrator': Airbus's industrial organisation model', International Journal of Technology and Globalisation, Vol. 7, Nos.

$1 / 2$, pp.8-22.

Krugman P., 1995. Rendements croissants et géographie économique, dans A. Rallet et $A$. Torre (eds), Economie industrielle et économie spatiale, Economica, Paris.

Langlois R.N. (2002), Modularity in Technology and organization, Journal Of Economic Behavior \& Organization, vol. 49, p. 19-37.

Lorenzi G., Baden-Fuller C., 1995. Creating a strategic center to manage web of partners, Californian Management Review, vol. 37, n³, 147-163.

MacKinnon D., Cumbers A., Pike A., Birch K., McMaster R., 2009. Evolution in Economic Geography: Institutions, Political Economy, and Adaptation, Economic Geography, vol. 85, $n^{\circ} 2,129-150$.

MacKinnon, D, Derickson, K., 2013. From resilience to resourcefulness: A critique of resilience policy and activism, Progress in Human Geography, vol. 37, n², 253-270.

Meyer, A. D. (1982). Adapting to environmental jolts. Administrative Science Quarterly, 27(4), 515 
Meyer, A. D., Brooks, G. R., \& Goes, J. B. (1990). Environmental jolts and industry revolutions: Organizational responses to discontinuous change. Strategic Management Journal, 11(4), 93-110.

Miles R., Snow, C., 1992. Causes of failure in network organizations, Californian Management Review, vol. 34, $n^{\circ} 4$. 53-72.

Moati, P., Mouhoud, E.M., (1994), Information et organisation de la production. Vers une division cognitive du travail, Economie Appliquée, tome XLVI, ${ }^{\circ} 1$, pp.47-73.

Pauchant, T. C. (1988). An annotated bibliography in crisis management, Working paper, Québec, HEC Montréal.

Pike A., Dawley S. Tomaney J., 2010. Resilience, adaptation and adaptability, Cambridge Journal of Territories, Economy and Society, vol. 3, n¹, 59-70.

Riolli L., Savicki V. Information system organizational resilience, Omega, Volume 31, Issue 3, June 2003, Pages 227-233

Rugman A.M., D’Cruz J.R., 2000. Multinationals as flagship firms, Oxford University Press.

Simmie J., Martin R., 2010. The economic resilience of territories: towards an evolutionary approach, Cambridge Journal of Territories, Economy and Society, vol. 3, n¹, 27-43.

Sturgeon, T. (2002) 'Modular Production Networks: A New American Model of Industrial Organization', Industrial and Corporate Change,11(3): 451-96.

Suire R., Vicente J, 2009. Why do some places succeed when others decline? A social interaction model of cluster viability, Journal of Economic Geography, vol. 9, issue 3, 381404.

Swanstrom T., 2008. Territorial Resilience: A Critical Examination of the Ecological Framework. University of California, Berkeley, IURD, Working Paper 2008-07.

Talbot D., 2010. La dimension politique dans l'approche de la proximité, Géographie, Economie, Société, vol. 22, n², 125-144.

Talbot D., 2013. Clustérisation et délocalisation: les proximités construites par Thales Avionics. Revue française de gestion. Forth coming. 
Vaughan, D. (2005). System effects: On slippery slopes repeating negative patterns and learning from mistake? In W. H. Starbuck \& M. Farjoun (Eds.), Organization At The Limit: Lessons From The Columbia Disaster (pp. 41-59). Malden, MA: Blackwell.Farjoun (Eds.).

Weick, K. E. (1990). The vulnerable system: An analysis of the Tenerife air disaster. Journal of Management, 16(3), pp. 571-593.

Weick, K. E. (1993). The collapse of sensemaking in organizations: The Mann Gulch disaster. Administrative Science Quarterly, 38(4),

Weick, Karl E., and Karlene H. Roberts. 1993. "Collective mind in organizations: Heedful interrelating on flight decks." Administrative Science Quarterly, 38: 357- 381. 